\title{
A MATHEMATICAL MODEL FOR CONTROLLING A QUADROTOR UAV
}

\author{
Rafał Kowalik $^{1^{*}}$ (iD 0000-0001-6431-9561 \\ Tomasz Lusiak $^{2}$ (D) 0000-0003-2324-4596 \\ Andrej Novak ${ }^{3}$ (i) 0000-0001-9567-5104 \\ ${ }^{1}$ Military University of Aviation, ul. Dywizjonu 303 no. 35 08-521 Dęblin, Poland \\ ${ }^{2}$ Lublin University of Technology, ul. Nadbystrzycka 38 D, 20-618 Lublin, Poland \\ ${ }^{3}$ University of Žilina, Univerzitná 8215/1, 01026 Žilina, Slovakia \\ *r.kowalik@law.mil.pl
}

\begin{abstract}
Given the recent surge in interest in UAVs and their potential applications, a great deal of work has lately been done in the field of UAV control. However, UAVs belong to a class of nonlinear systems that are inherently difficult to control. In this study we devised a mathematical model for a PID (proportional integral derivative) control system, designed to control a quadrotor UAV so that it follows a predefined trajectory. After first describing quadrotor flight dynamics, we present the control model adopted in our system (developed in MATLAB Simulink). We then present simulated results for the use of the control system to move a quadrotor UAV to desired locations and along desired trajectories. Positive results of these simulation support the conclusion that a quadrotor UAV spatial orientation control system based on this model will successfully fulfil its task also in real conditions.
\end{abstract}

Keywords: UAV control system, dynamics model, quadrotor, linearization

Type of the work: Research Article

\section{CONTROL SYSTEMS FOR UNMANNED AERIAL VEHICLES (UAVS)}

Multi-rotor flying platforms are a relatively young and dynamically developing field. Such devices are finding more and more applications, but they are still struggling with unsolved problems. With advances made in the development of materials, electronics, sensors and batteries, the size of micro UAVs now ranges from 0.1 to 0.5 metres in length and 0.1 to $5 \mathrm{~kg}$ in weight. The construction of a simple flying object of this type seems to be extremely simple, however, it poses serious challenges for designers and programmers. Due to the nature of the platform, active thrust control must be applied to maintain the robot in the air. Although simple PID (proportional integral derivative) controllers are sufficient for flight stabilisation, achieving control quality that allows practical use of this type of platform is still a challenge.

A class of unmanned aircraft with four rotors, known as quadrotors, is becoming increasingly popular. Given this surge of interest, much effort has lately gone into developing new control methods for quadrotors in particular. One example can be found in the HMX-4, which is a kind of quadrotor about 
$0.7 \mathrm{~kg}$ in weight, $76 \mathrm{~cm}$ in length between the ends of the rotor axes, and with flight time of about 3 minutes. Due to the weight limitation of this type of aircraft, no GPS or other instrumentation (such as accelerometers) can be added. Position and velocity data can be obtained via cameras. For feedback, it has an early micro electromechanical system (MEMS) for the pilot-assistant. The feedback linearisation controller controls the altitude and yaw angle. Because the qaudrotor drifts in the $x^{-} y$ plane under the control of this controller, a reversing controller is needed for attitude control.

Another commonly studied testbed uses a proportional-embedded PID controller to jointly control position and attitude $[1,2,3,12,13]$. The AscTec Hummingbird is a typical model of this type of quadrotor. This model has a wood or carbon fibre frame, making it robust and lightweight, at around $0.5 \mathrm{~kg}$. These quadrotors have their own sensors for obtaining states. The controller regulates the plant based on the difference between the set points and the measured values. Another PID control system used is the STARMAC test table. This quadrotor has a weight of about $1.1-1.6 \mathrm{~kg}$ and can carry an additional payload of about $2.5 \mathrm{~kg}$. One of the externally available trajectory tracking models is called the X4-flyer. This controller was developed to reduce vehicle orientation and keep it very low. The dynamic model was obtained using the Euler-Langrage method. The PID controller is used to control the hovering unmanned vehicle or track its trajectory $[4,5,6,14,15]$.

\section{Dynamics and control model}

The rotors are designed to transmit force upward; their rotation also introduces torques. The forces and moments produced depend on the rotor speed. The main challenge is to control the appropriate speeds of the four rotors to ensure stable flight along the desired trajectory.

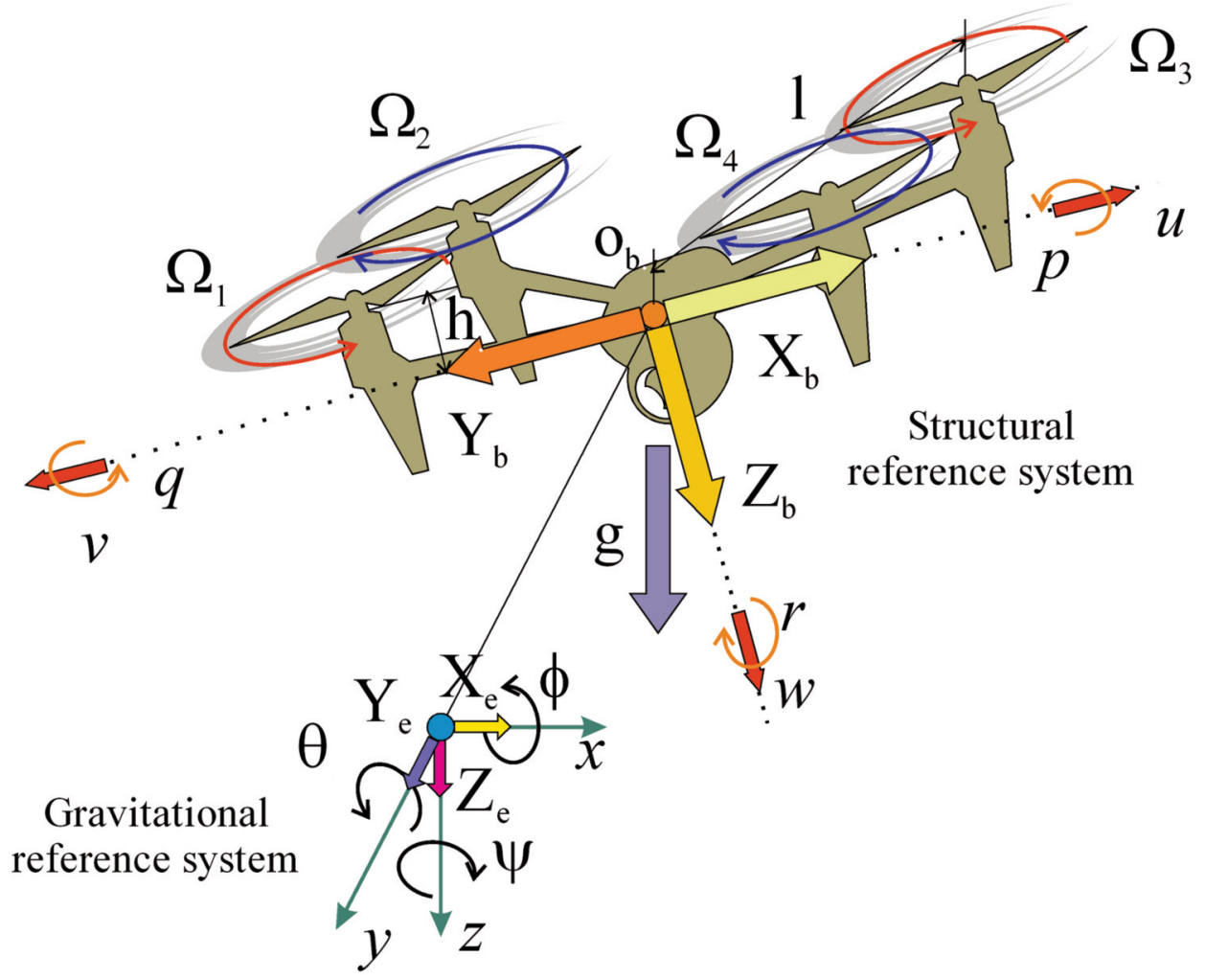

Fig. 1. Simplified illustration of rotor movement and quadrotor rotor control. 
Figure 1 shows a simplified representation of how the rotors control the movement of a quadrotor. Rotors 1 and 3 rotate counter-clockwise and produce torque in the clockwise direction; conversely, rotors 2 and 4 rotate in a clockwise direction and produce torque in a counter-clockwise direction. All rotors produce force in the upward direction perpendicular to the plane of rotation. In the example shown in Fig. 1, the rotational speeds of rotors 2 and 4 are greater than those of rotors 1 and 3 . The effective torque will therefore be in the counter-clockwise direction, and the quadrotor will deflect in the counter-clockwise direction. When the four rotors have the same rotational speed, the momentum in the counter-clockwise direction will balance the momentum in the clockwise direction.

\section{Dynamic model}

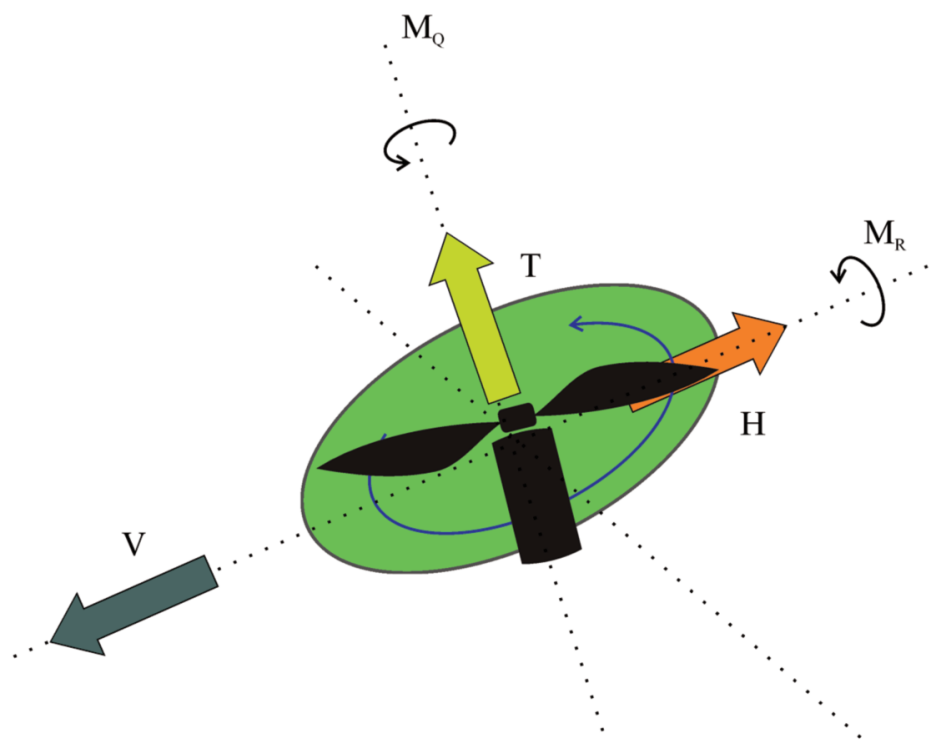

Fig. 2. Motion parameters in the propeller system of a UAV object.

In order to develop a dynamic model of the quadrotor, we position the fuselage frame so that it is on the main axis of the quadrotor. As shown in Figure 1, the origin of the fuselage frame is positioned at the centre at point $\mathrm{O}$ of the quadrotor. One arm is selected as the $\mathrm{X}$ axis and the other as the $\mathrm{Y}$ axis.

The structural frame of the UAV is denoted by the letter $\mathrm{w}$ and labelled $\mathrm{X}_{\mathrm{w}}, \mathrm{Y}_{\mathrm{w}}, \mathrm{Z}_{\mathrm{w}}$ as shown in Fig. 5. The body frame is denoted by B. The red chain lines in Fig. 3 are connected to form a simple quadrotor diagram. Each line indicates the rotors of the quadrotor. The body frame is fixed at point $\mathrm{O}$. Point $\mathrm{O}$ is the centre of mass of the quadrotor rotors. The direction pointing from $\mathrm{O}$ to rotor No. 1 is defined as the positive direction $\mathrm{X}_{\mathrm{B}}$. In contrast, the direction forward to No. 3 is a negative $\mathrm{X}_{\mathrm{B}}$ direction. Similarly, the direction pointing from $O$ to rotor No. 2 is defined as positive direction $Y_{B}$, and the direction forward to rotor No. 4 is negative direction $Y_{B}$. The $Z_{B}$ direction is the direction from point $\mathrm{O}$ in the opposite direction of gravity. The body rotates about $\mathrm{Z}_{\mathrm{W}}$ by a yaw angle $\psi$, rotates about the intermediate point $\mathrm{x}$ by a roll angle $\Phi$, and rotates about the $\mathrm{Y}_{\mathrm{B}}$ axis by an inclination angle, $\theta$. The rotation of the coordinate transformation matrix from $\mathrm{B}$ to $\mathrm{w}$ is [7]:

$$
R=\left[\begin{array}{ccc}
\cos \psi \cos \theta-\sin \sin \psi \sin \theta & \cos \Phi \sin \psi & \cos \psi \sin \theta+\cos \theta \sin \Phi \sin \psi \\
\cos \theta \sin \psi+\cos \psi \sin \sin \theta & \cos \Phi \cos \psi & \sin \psi \sin \theta-\cos \psi \cos \theta \sin \Phi \\
-\cos \Phi \sin \theta & \sin \Phi & \cos \Phi \cos \theta
\end{array}\right]
$$




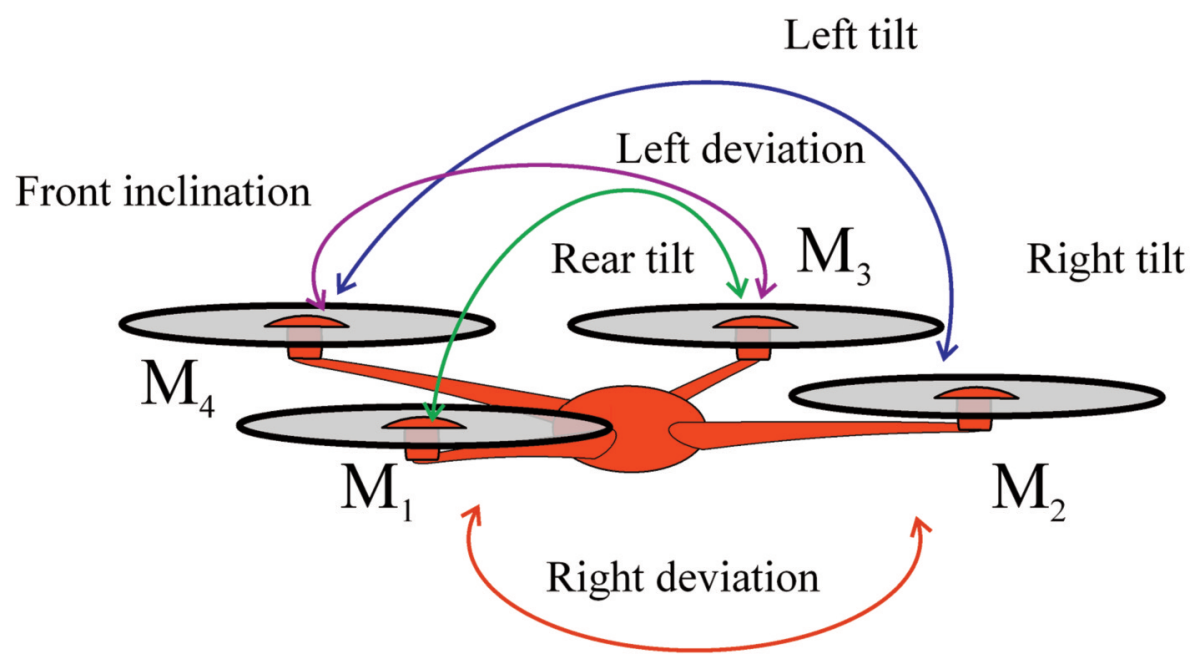

Fig. 3. Diagram showing yaw, roll and pitch angles.

If $\mathrm{r}$ is the position vector of the centre of mass in the UAV frame, the acceleration of the centre of mass is given by the equation [8]:

$$
m \ddot{r}=\left[\begin{array}{c}
0 \\
0 \\
-m g
\end{array}\right]+R\left[\begin{array}{c}
0 \\
0 \\
\sum F i
\end{array}\right]
$$

In the body frame, the components of the angular velocity of the robot are $\mathrm{p}, \mathrm{q}$ and $\mathrm{r}$.

The relationship between these values and the angle derivatives of yaw, roll, pitch are [9]:

$$
\left[\begin{array}{l}
p \\
q \\
r
\end{array}\right]=\left[\begin{array}{ccc}
\cos \theta & 0 & -\cos \Phi \sin \theta \\
0 & 1 & \sin \Phi \\
\sin \theta & 0 & \cos \Phi \cos \theta
\end{array}\right]\left[\begin{array}{l}
\dot{\Phi} \\
\dot{\theta} \\
\dot{\psi}
\end{array}\right]
$$

Each rotor $i$ produces a moment $M_{\mathrm{i}}$ which is perpendicular to the plane of rotation. Rotors 1 and 3 produce moments in the $-\mathrm{Z}_{\mathrm{B}}$ direction. The moments of rotors 2 and 4 are in the opposite direction: $\mathrm{Z}_{\mathrm{B}}$. The torque produced on the quadrotor is opposite to the direction of rotation of the blades, so that $M 1$ and $M 3$ act in the ZB direction, while $M 2$ and $M 4$ act in the opposite direction. The distance from the rotors' axis of rotation to the centre of the rotor is denoted by the letter L. By comparing the individual components of the quadrotor, the moment of inertia, I, is related to the centre of gravity along the $\mathrm{X}_{\mathrm{B}}-\mathrm{Y}_{\mathrm{B}}-\mathrm{Z}_{\mathrm{B}}$ axis. The angular acceleration is obtained using Euler's equations, as shown below:

$$
I=\left[\begin{array}{c}
\dot{p} \\
\dot{q} \\
\dot{r}
\end{array}\right]=\left[\begin{array}{c}
L\left(F_{2}-F_{4}\right) \\
L\left(F_{3}-F_{1}\right) \\
M 1-M 2+M 3-M 4
\end{array}\right]-\left[\begin{array}{l}
p \\
q \\
r
\end{array}\right] \times I\left[\begin{array}{l}
p \\
q \\
r
\end{array}\right]
$$




\section{Position control}

In this paper, we present the mathematical model for a PID controller for quadrotor control. The controller adjusts the process control inputs to minimize the error, which is the value of the difference between the measured process variable and the desired setpoint [10]. The roll and pitch angles are placed on the input. Using a backward step approach, two types of position control methods can be obtained. One is the UAV hover execution controller, which will control the rotor to maintain the rotor in the desired position. The other is a four-rotor control for tracking arbitrary trajectories in $3 \mathrm{D}[11,16,17]$.

\section{Flight control controller}

The quadrotor will hover when the nominal propulsion of the propellers is equal to the force of gravity, in other words when:

$$
F_{i, 0}=\frac{m g}{4}
$$

and the engine speed:

$$
\omega_{i, 0}=w_{h}=\sqrt{\frac{m g}{4 k_{F}}}
$$

$r_{T}(\mathrm{t})$ - the trajectory position, $\psi_{T}(\mathrm{t})$ - the yaw angles, which are the path.

Note that $\psi_{T}(\mathrm{t})=0$ for the UAV flight controller. The position error is given by:

$e_{i}=\left(r_{i, T}-r_{i}\right)$

The recommended acceleration $\ddot{r}_{i}^{\text {des }}$ can be calculated using the PID law:

$\left(\ddot{r}_{i, T}-\ddot{r}_{i}^{d e s}\right)+k_{d, i}\left(\dot{r}_{i, T}-\dot{r}_{i}\right)+k_{p, i}\left(r_{i, T}-r_{i}\right)+k_{i, i} \int\left(r_{i, T}-r_{i}\right)=0$

For hovering:

$\dot{r}_{i, T}=\ddot{r}_{i, T}=0$

The relationship between desired accelerations and roll, pitch angles is as follows:

$$
\begin{aligned}
\ddot{r}_{1}^{d e s} & =g\left(\theta^{\text {des }} \cos \psi_{T}+\phi^{\text {des }} \sin \psi_{T}\right) \\
\ddot{r}_{2}^{d e s} & =g\left(\theta^{\text {des }} \sin \psi_{T}+\phi^{\text {des }} \cos \psi_{T}\right) \\
\ddot{r}_{3}^{\text {des }} & =\frac{8 k_{F} \omega_{h}}{m} \Delta \omega_{F} \\
\phi^{d e s} & =\frac{1}{g}\left(\ddot{r}_{1}^{\text {des }} \sin \psi_{T}-\ddot{r}_{2}^{d e s} \cos \psi_{T}\right) \\
\theta^{\text {des }} & =\frac{1}{g}\left(\ddot{r}_{1}^{\text {des }} \cos \psi_{T}-\ddot{r}_{2}^{d e s} \sin \psi_{T}\right) \\
\Delta \omega_{F} & =\frac{m}{8 k_{F} \omega_{h}} \ddot{r}_{3}^{d e s}
\end{aligned}
$$




\section{Height control}

In the case of hovering, $\dot{\phi} \approx p, \theta \approx q, \psi \approx r$, proportional-derivative control laws are used in a way:

$$
\begin{aligned}
& \Delta \omega_{\phi}=k_{p, \phi}\left(\phi^{\text {des }}-\phi\right)+k_{p, \phi}\left(p^{\text {des }}-p\right) \\
& \Delta \omega_{\theta}=k_{p, \theta}\left(\theta^{d e s}-\theta\right)+k_{p, \theta}\left(q^{d e s}-q\right) \\
& \Delta \omega_{\mathrm{E}}=k_{p, \grave{\mathrm{E}}}\left(\grave{\mathrm{E}}^{d e s}-\grave{\mathrm{E}}\right)+k_{p, \grave{\mathrm{E}}}\left(r^{\text {des }}-r\right) \\
& I_{x x} \dot{p}=L k_{F}\left(\omega_{2}^{2}-\omega_{4}^{2}\right)-q r\left(I_{z z}-I_{y y}\right) \\
& I_{y y} \dot{q}=L k_{F}\left(\omega_{3}^{2}-\omega_{1}^{2}\right)-p r\left(I_{x x}-I_{z z}\right) \\
& I_{z z} \dot{r}=k_{M}\left(\omega_{1}^{2}-\omega_{2}^{2}-\omega_{3}^{2}-\omega_{4}^{2}\right)
\end{aligned}
$$

From the above equation we obtain the result for $\omega$ :

$$
\left[\begin{array}{c}
\omega_{1}^{d e s} \\
\omega_{2}^{d e s} \\
\omega_{3}^{d e s} \\
\omega_{4}^{d e s}
\end{array}\right]=\left[\begin{array}{cccc}
1 & 0 & -1 & 1 \\
1 & 1 & 0 & -1 \\
1 & 0 & 1 & 1 \\
1 & -1 & 0 & -1
\end{array}\right]\left[\begin{array}{c}
\omega_{h}+\Delta \omega_{F} \\
\Delta \omega_{\phi} \\
\Delta \omega_{\theta} \\
\Delta \omega_{\grave{E}}
\end{array}\right]
$$

\section{Simulation of a dynamic model}

This section presents the numerical simulation results for the validation of the dynamic and control model discussed in the previous section. The parameters used for the simulation are shown below in Table 1.

Tab. 1. Parameters of the dynamic model.

\begin{tabular}{|l|l|l|}
\hline $\mathrm{Kpx}=1$ & $\mathrm{Kpy}=1$ & $\mathrm{~K}_{\mathrm{pz}}=1$ \\
\hline $\mathrm{Kdx}=1$ & $\mathrm{Kdy}=1$ & $\mathrm{~K}_{\mathrm{dz}}=1$ \\
\hline $\mathrm{kF}=6.11^{*} 10^{-8} \mathrm{~N} /\left(\mathrm{r} / \mathrm{min}^{2}\right)$ & $\mathrm{KM}=1.5^{*} 10^{-9} \mathrm{~N} /\left(\mathrm{r} / \mathrm{min}^{2}\right)$ & $\mathrm{K}_{\mathrm{m}}=20$ \\
\hline $\mathrm{M}=1.08 \mathrm{~kg}$ & $\mathrm{G}=9.8 \mathrm{~m} / \mathrm{s}^{2}$ & $\mathrm{~L}=0.22 \mathrm{~m}$ \\
\hline
\end{tabular}

Based on the dynamic model of the quadrotor, the control model was developed in MATLAB Simulink. For the simulation, the quadrotor flies from the initial position $(0,0,0)$ to the final location $(10,10,10)$ and hovers over this point $(10,10,10)$. The distance units given here are expressed in metres. Fig. 4 shows the actual path the quadrotor travels. 


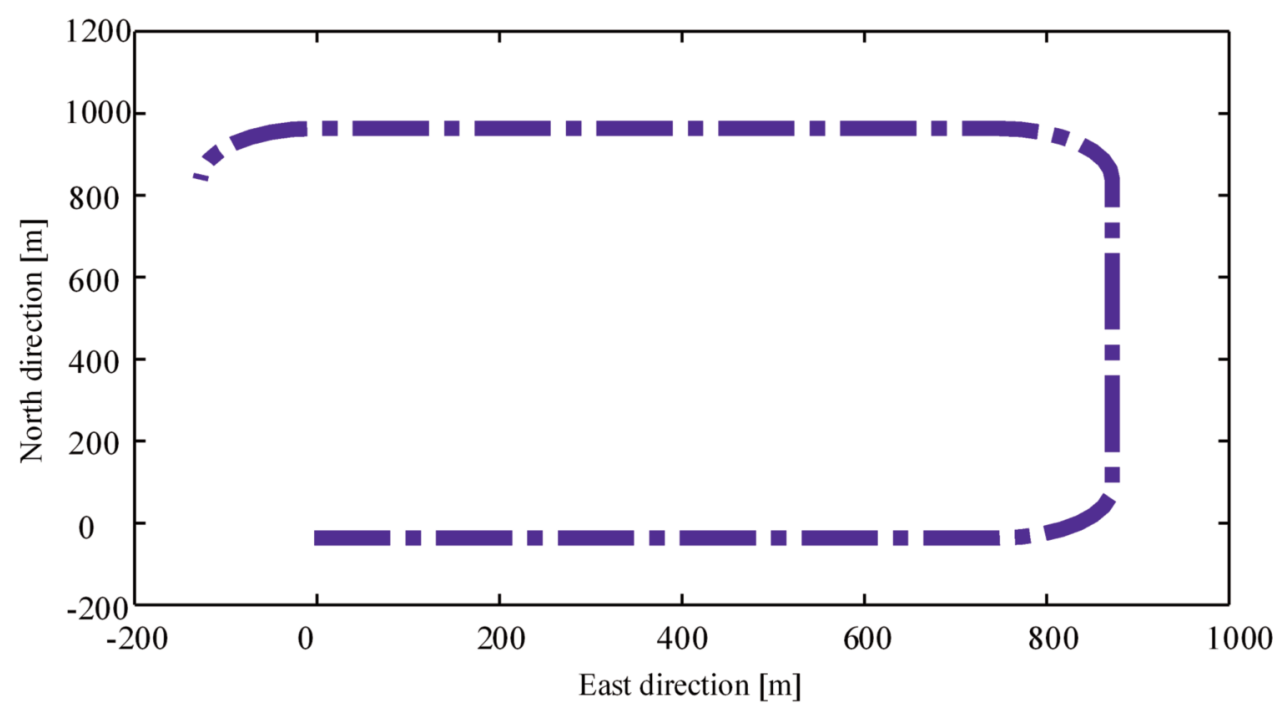

Fig. 4. Simulated trajectory of the quadrotor.

Figs. 5, 6 and 7 show $\mathrm{x}, \mathrm{y}$, $\mathrm{z}$ plots of the quadrotor position as a function of time as this UAV moves from the initial position to the desired position.

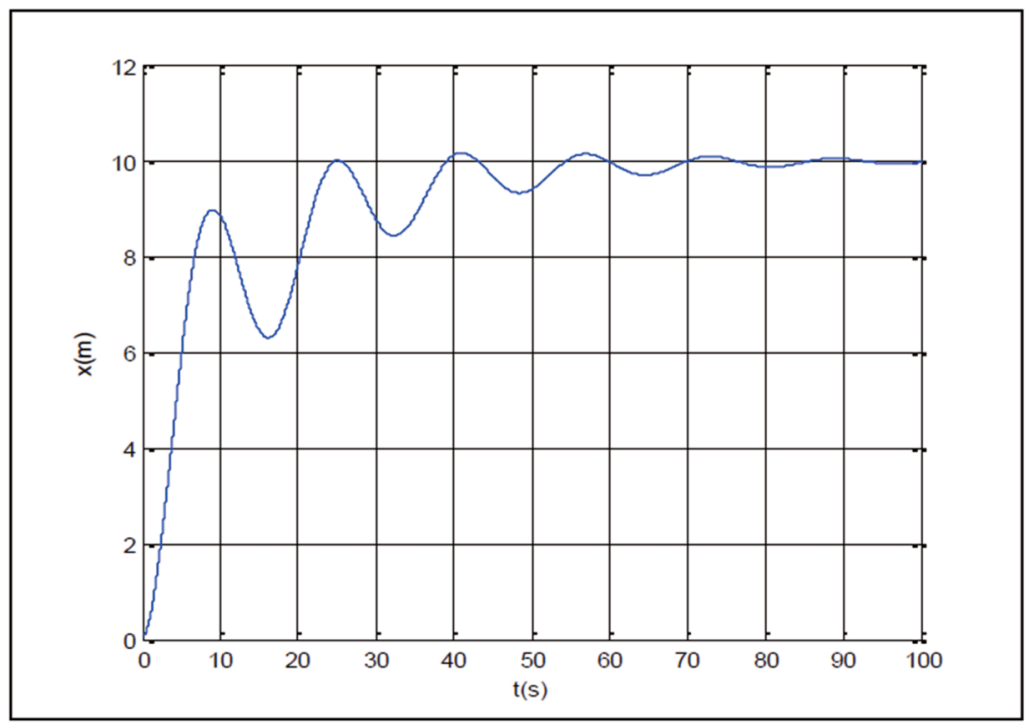

Fig. 5. Simulation result showing $\mathrm{x}$ position of quadrotor versus time. 


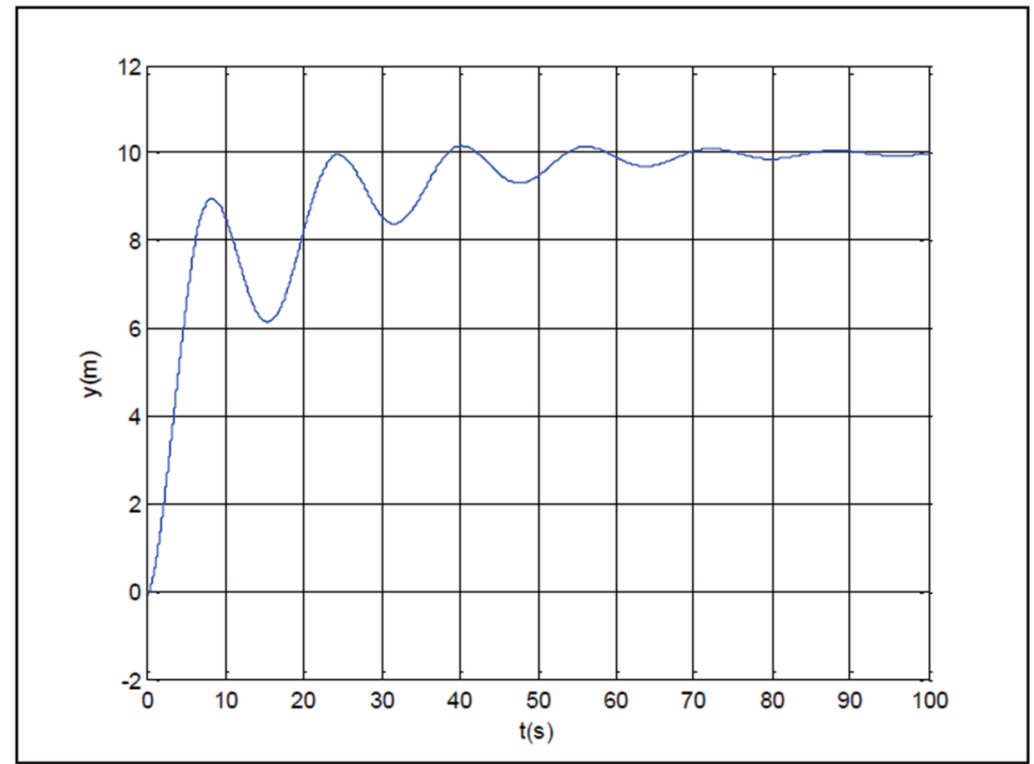

Fig. 6. Simulation result showing y position of quadrotor versus time.

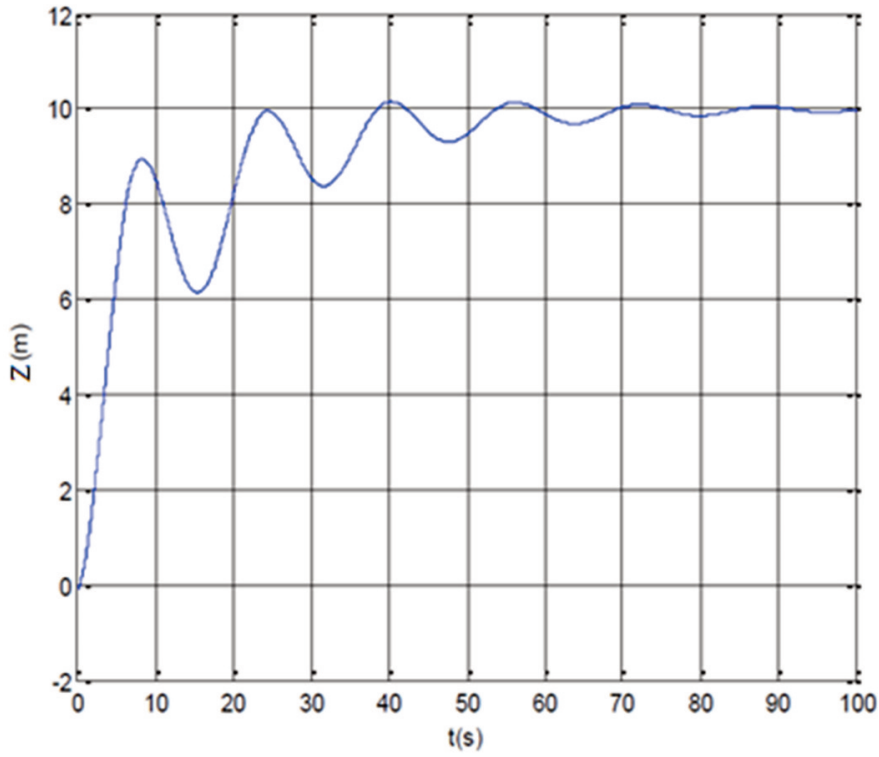

Fig. 7. Simulation result showing z position of quadrotor versus time.

To further verify the dynamic and control model with respect to following a desired trajectory (or target location), the quadrotor was put into motion along a circle with a centre at $(5,0)$ and a radius of $5 \mathrm{~m}$. Fig. 8 shows the simulation result of the desired and actual trajectory of the quadrotor following the circular trajectory. Figs. 9 and 10 show the simulation result for the desired $\mathrm{x}$ and actual $\mathrm{x}$, desired $\mathrm{y}$ and actual $y$ for the circular path. 


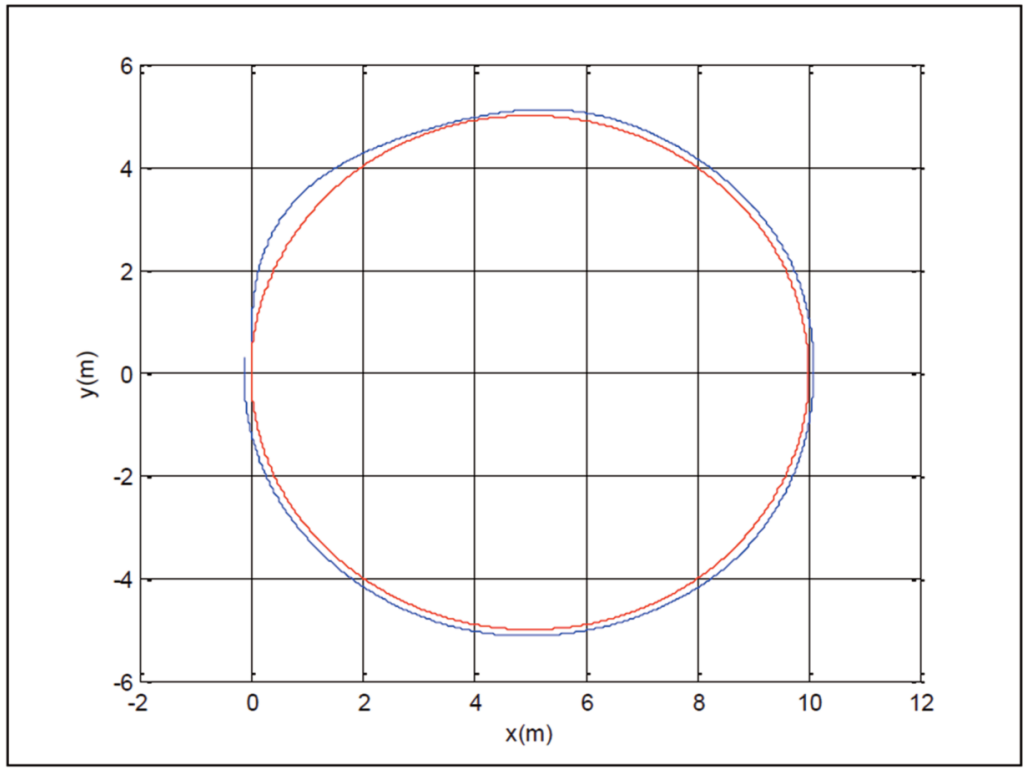

Fig. 8. Simulation result showing the desired (red) and actual trajectory (blue) of a quadrotor following a circular trajectory.

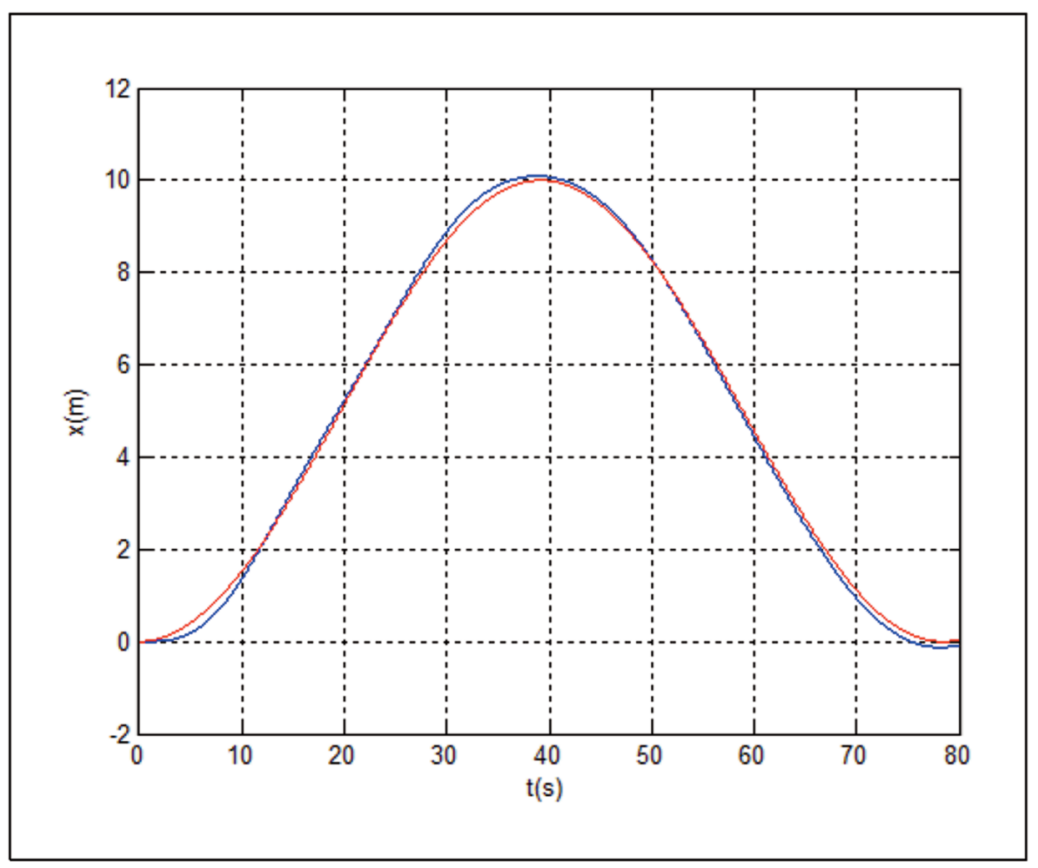

Fig. 9. Simulation result showing the desired $\mathrm{x}$ (red) and the actual $\mathrm{x}$ (blue) of the quadrotor following a circular trajectory. 


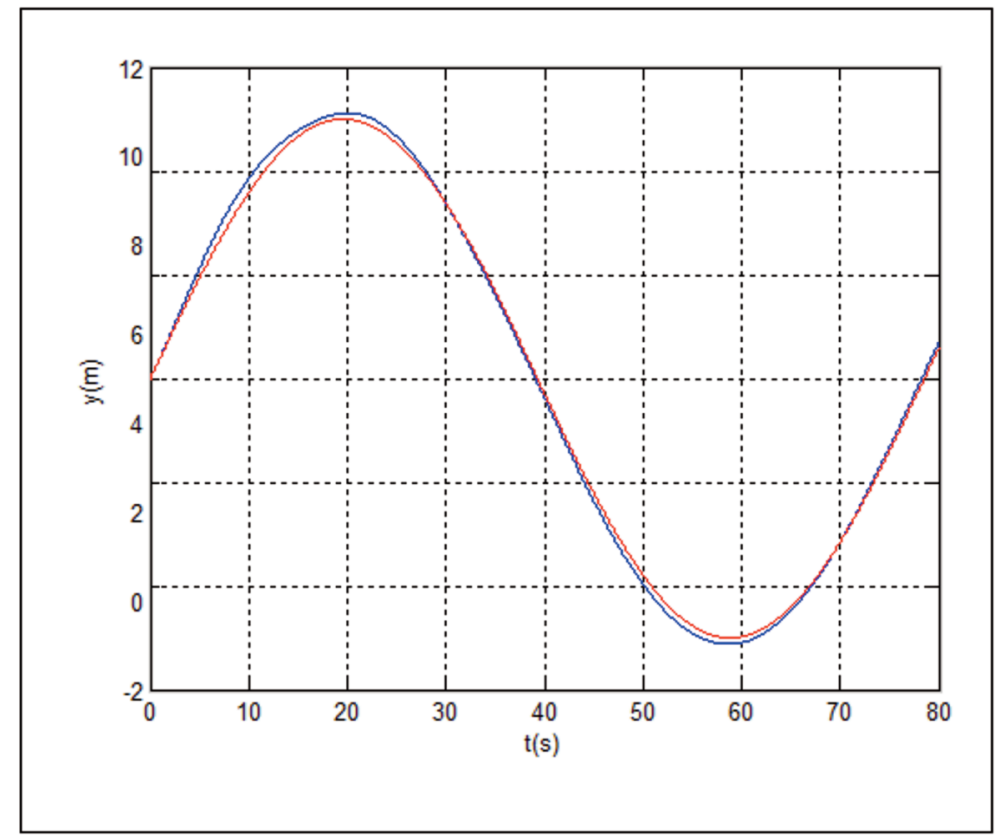

Fig. 10. Simulation result showing the desired y (red) and the actual y (blue) of the quadrotor following a circular trajectory.

The control model was then verified, showing that the quadrotor moves from its resting position to the desired location and lands again. Fig. 11 shows a simulation of UAV motion. The quadrotor took off at point $(0,0,0)$ flew to point $(0,0,10)$, then was rotated and moved to point $(10,10,10)$ and then landed at point $(10,10,0)$.

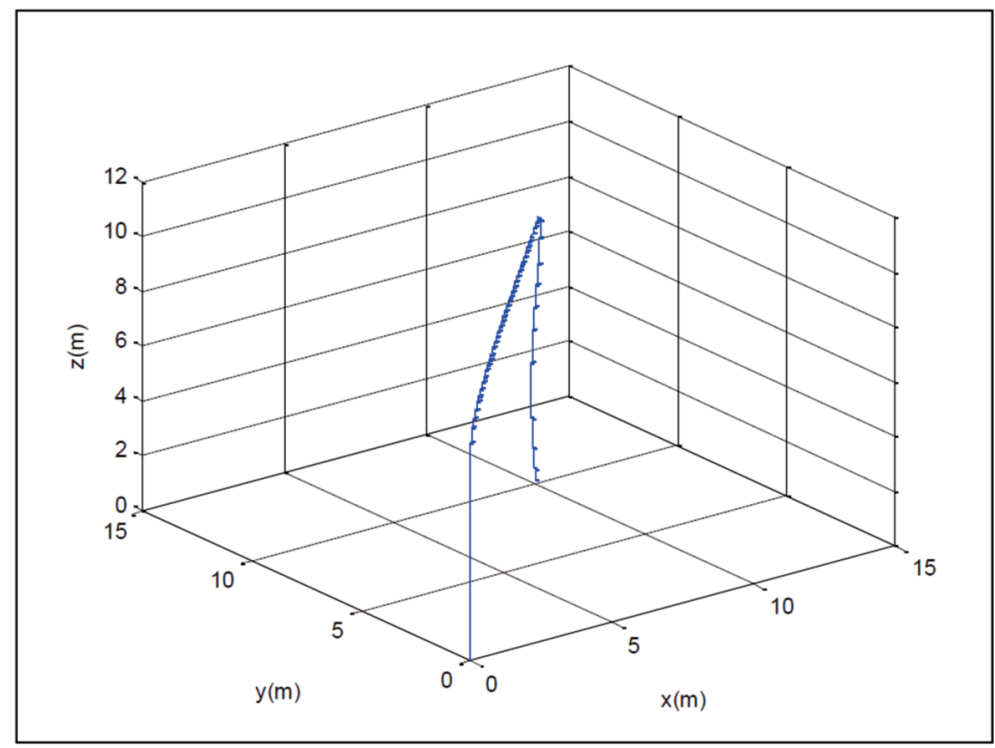

Fig. 11. Simulation of the outcome of the quadrotor's movement to successive desired locations. 
The above numerical simulations showed that the quadrotor was able to navigate to any waypoint locations and follow any desired trajectories.

Fig. 12 shows selected flight parameter waveforms presenting the operation of the unmanned aerial vehicle control system during the landing phase with the use of the on-board vision system. The data presented in the diagrams were obtained in simulations. The graphs obtained show that the applied algorithm allows a satisfactory quality of control of the aircraft to be achieved in the landing phase.
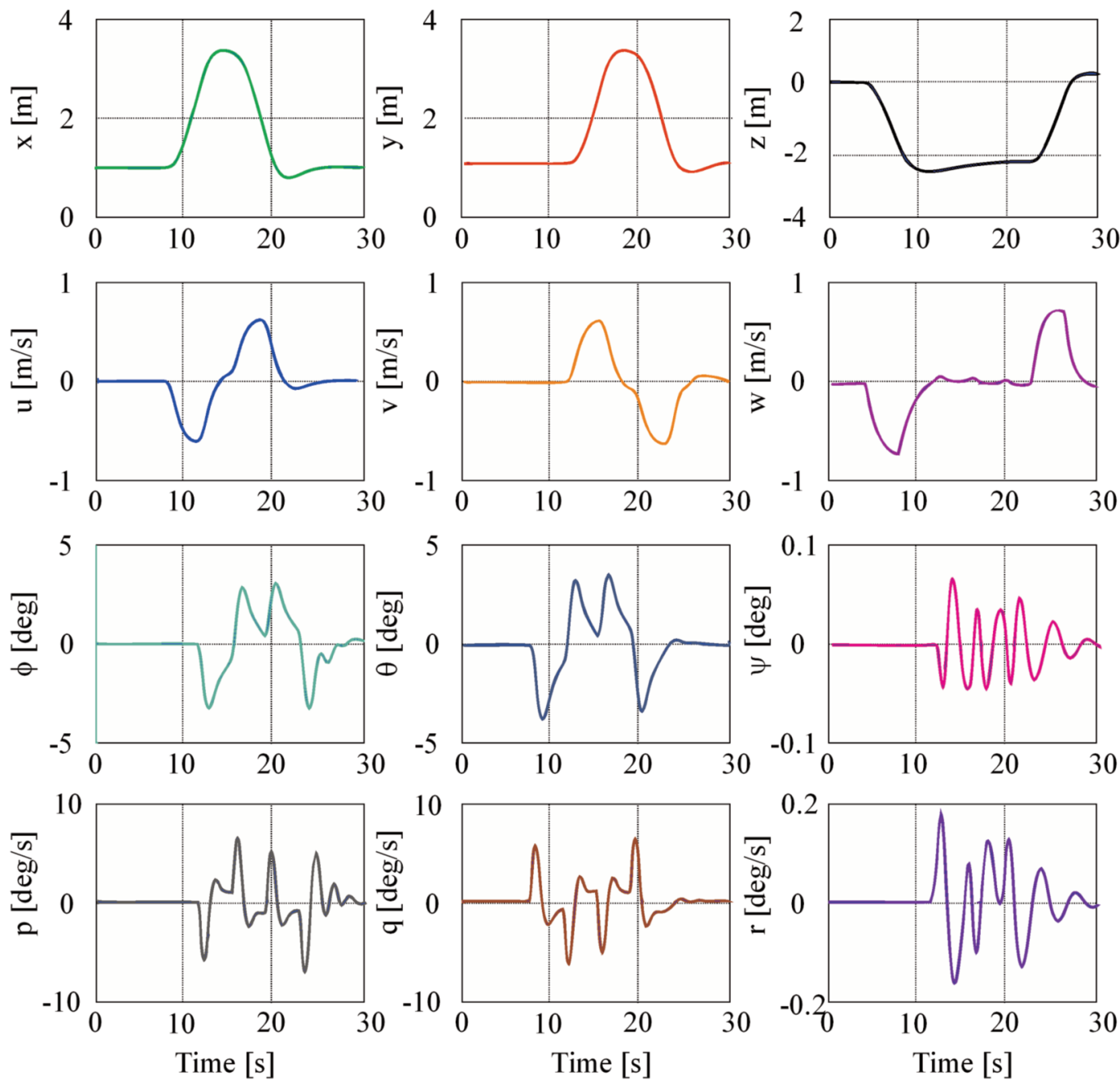

Fig. 12. Simulation of the resulting movement in three axes $\mathrm{x}, \mathrm{y}, \mathrm{x}$ as read by the controller.

\section{CONCLUSIONS}

Existing control algorithms for multi-rotor UAV platforms leave room for superior systems that control altitude, position and flight trajectory while aiming at full autonomy of the aerial vehicle. The first obstacle to overcome in achieving this goal is the incorrect design of the mechanical structure. As a flying apparatus, a multi-rotor craft needs to have a very low empty weight while providing adequate rigidity and strength. At the same time, a key issue is the quality of the orientation measurement, essential 
in the platform stabilisation process. As the rigidity of the superstructure increases, the quality of control improves due to the smaller influence of the structural deformations on forces and measurements. At the same time, however, the impact of the interference generated by the moving elements and especially by the drive units on the quality of measurements increases.

In this study, we focused on two problems:

1) obtaining a dynamic quadrotor model

2) route planning and route planning optimisation.

With respect to the first problem, the dynamics of the quadrotor was analysed and then a controller based on the PID method was developed. In this part, parameters were chosen to make this simulation model almost identical to a real quadrotor. Point-to-point navigation and trajectory experiments were then carried out using the simulation model developed based on the dynamics of the quadrotor. The results showed that the model worked well in practice. For the second problem, a trajectory of full coverage of a defined area was developed. Trajectory parameters were identified and the Langrage multiplier algorithm was used to obtain those parameters that minimised the total time required to traverse the entire trajectory.

To recap, then, in the study reported herein, we developed a mathematical model of quadrotor dynamics, which we then used, after its linearisation, to design a spatial orientation control system. Positive results of simulation tests allow us to assume that this system will fulfil its task also in real conditions.

\section{REFERENCES}

[1] Allen, M. and Lin, V., 2007, Guidance and Control of an Autonomous Soaring UAV, NASA/TM2007-214611.

[2] Choi, H.S., Lee, S., Lee, J., Kim, E.T., and Shim, H., 2010, “Aircraft Longitudinal Auto-landing Guidance Law Using Time Delay Control Scheme," Transactions of the Japan Society for Aeronautical and Space Sciences, 53(181), pp. 207-214. doi: 10.2322/tjsass.53.207.

[3] Choi, H.S., Lee, S., Ryu, H., Shim, H. Ha, C., 2015, "Dynamics and Simulation of the Effects of Wind on UAVs and Airborne Wind Measurement," Transactions of the Japan Society for Aeronautical and Space Sciences, 58(4), pp. 187-192. doi: 10.2322/tjsass.58.187.

[4] Hwang, S., Kim, S., Kim, C., Lee, and Y.G., 2016, "Aerodynamic Design of the Solar-Powered High Altitude Long Endurance (HALE) Unmanned Aerial Vehicle," International Journal of Aeronautical and Space Sciences, 17(1), pp. 132-138. doi: 10.5139/IJASS.2016.17.1.132.

[5] Langelaan, J.W., Alley, N., and Neidhoefer, J., 2010, "Wind Field Estimation for Small Unmanned Aerial Vehicles," AIAA Guidance, Navigation and Control Conference.

[6] Lee, B., Park, P., Kim, K., Kwon, S., 2014, "The Flight Test and Power Simulations of an UAV Powered by Solar Cells, a Fuel Cell and Batteries,” J. of Mechanical Science and Technology, 28, pp. 399-405. doi: 10.1007/s12206-013-0936-7.

[7] Lee, S., Lee, J., and Lee, D.S., 2012, "Lateral and Directional SCAS Controller Design Using Multidisciplinary Optimization Program,” J. Korean Soc. Aeronaut. Space Sci., 40(3), pp. 251-257. doi: 105139/JKSAS.2012.40.3.251

[8] Osborne, J. and Rysdyk, R., 2005. Waypoint Guidance for Small UAVs in Wind, AIAA Infotech@Aerospace.

[9] Setlak, L., Kowalik, R., and Redo, W., 2018, "Study of multi-pulse rectifiers of the PES system inaccordance with the concept of a more electric aircraft," WSEAS Transactions on Systems and Control, 13, Art. \#20, pp. 161-170.

https://www.wseas.org/multimedia/journals/control/2018/a405903-039.pdf 
[10] Yoon, S. and Kim, Y., 2012, "Constrained Adaptive Backstepping Controller Design for Aircraft Landing in Wind Disturbance and Actuator Stuck,” Int. J. Aeronaut. Space Sci., 13(1), pp. 74-89. doi: 10.5139/IJASS.2012.13.1.74

[11] Zhen, Li, Tiansheng, Hong, Ning, Wang, Tao, Wen, 2010, "Data transmission performance for 2.4GHz in-field wireless sensor network," 2nd International Conference on Computer Engineering and Technology (ICCET), vol. 1, pp. V1-465-V1-469.

[12] Ažaltovič, V., Škvareková, I., Pecho, P., and Kandera, B., 2020, "Calculation of the ground casualty risk during aerial work of unmanned aerial vehicles in the urban environment," Transportation Research Procedia, 44, pp. 271-275. doi: 10.1016/j.trpro.2020.02.043.

[13] Bugaj, M., Urminsky, T., Jurák, P., and Pecho, P., 2018, „Analysis and implementation of airworthiness directives," Transport Means - Proceedings of the International Conference, pp. 11741178.

[14] Cerňan, J., Pecho, P., Cúttová, M., and Semrád, K., 2018, "Structural analysis of centrifugal compressor impellers with different blade shapes," Transport Means - Proceedings of the International Conference, pp. 972-977.

[15] Čerňan, J. and Hocko, M., 2019, “The investigation of turbine blades damage in small jet engine," Transport Means - Proceedings of the International Conference, pp. 1285-1290.

[16] Fördös, P. and Čerňan, J., 2020, "Analysis of the impact of hard PVD coatings on the abrasion resistance of the compressor blades," Advances in Military Technology, 15(1), 85-95. doi: 10.3849/aimt.01333.

[17] Sedláčková, A. N., Kurdel, P., and Labun, J. 2020, "Simulation of unmanned aircraft vehicle flight precision," Transportation Research Procedia, 44, pp. 313-320. doi: 10.1016/j.trpro.2020.02.037.

\title{
MODEL MATEMATYCZNY DO STEROWANIA CZTEROWIRNIKOWYM BSP
}

\begin{abstract}
Abstrakt
Wobec rosnącego zainteresowania bezzałogowymi statkami powietrznymi (BSP) i ich potencjalnymi zastosowaniami, w ostatnim czasie wykonano wiele prac w dziedzinie ich lepszego sterowania. BSP jednak należą do klasy nielinearnych systemów, które są z natury trudne do sterowania. W niniejszej pracy opracowano model matematyczny dla systemu sterowania opartego na metodzie PID (proportional integral derivative), zaprojektowanego do sterowania czterowirnikowym BSP tak, aby podążał on po wcześniej zdefiniowanej trajektorii. Opisano dynamiki lotu czterowirnikowym BSP i zaprezentowano model kontroli zastosowany w naszym systemie (opracowany w programie MATLAB Simulink). Przedstawione są wyniki symulacji użycia systemu do sterowania czterowirnikowym BSP w celu jego przemieszczenia się do pożądanej lokalizacji oraz wzdłuż pożądanej trajektorii. Wyniki tych symulacji potwierdzają wniosek, że oparty na tym modelu system sterowania dla czterowirnikowego BSP może z powodzeniem spełnić swoje zadanie również w warunkach rzeczywistych.
\end{abstract}

Słowa kluczowe: system kontroli BSP, model dynamiki, czterowirnikowy BSP, linearyzacja 